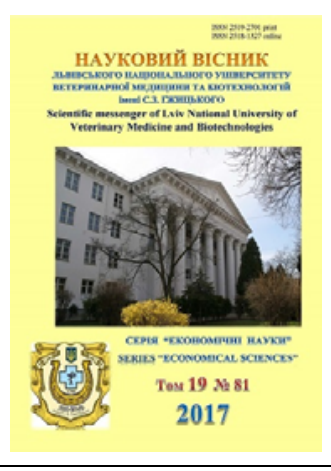

Науковий вісник Львівського національного університету ветеринарної медицини та біотехнологій імені С.3. Гжицького

Scientific Messenger of Lviv National University of Veterinary Medicine and Biotechnologies

doi:10.15421/nvlvet8113

ISSN 2519-2701 print

ISSN 2518-1327 online

http://nvlvet.com.ua/

УДК 338.432 (477.83)

\title{
Тенденції виробництва аграрної продукції суб'сктами господарювання Львівщини
}

\author{
М.Г. Шульський \\ pretty_62@ukr.net \\ Львівський національний університет ветеринарної медицини та біотехнологій імені С.3. Гжицького, \\ вул. Пекарська, 50, Львів, 79010, Україна
}

\begin{abstract}
В результаті проведених досліджень за обраною темою виявлено певні тенденції виробництва аграрної продукції як всіма категоріями господарств, так і в розрізі окремих їх груп. Для більш глибшого вникнення в суть процесів дослідження обрано тривалий період розвитку сільськогосподарського виробництва, а саме: період колишньої соціалістичної системи господарювання (1990р.) і період формування ринкових відносин та їх розвиток по сьогоднішній день (2000 p.; 2010 р.; 2015 p. і 2016 р.). Обрання таких часових рамок досліджень дозволило прослідкувати стан виробництва аграрної продукиії протягом тривалого періоду (1990-2016 рр.) і на основі одержаних результатів досліджень виявити певні тенденції. Обчислення індексів сільськогосподарської продукиії за категоріями господарств підтвердило наявність виявлених закономірностей.

Одержані результати дають вагомі підстави стверджувати, щзо питома вага виробництва аграрної продукції господарствами населення зростала з 1990 до 2000 р. (із 51,7\% до 90,2\%), а починаючи з 2000 р., цей показник поступово і динамічно зменшується із 90,2 у 2000 р. до 64,1\% у 2016 р. Сільськогосподарські підприємства характеризуються зворотніми тенденціями - їх частка динамічно збільшується. Ми вважаємо, щзо ие є закономірні процеси і вони будуть розвиватися й надалі. До якого часу? Відповіді на це питання можна дати лише тоді, коли провести нові дослідження за новою темою.

Ключові слова: тенденції, виробнищтво, аграрна продукція, суб'єкти господарювання, сільськогосподарські підприємства, господарства населення, сільське господарство.
\end{abstract}

\section{Trends in the production of agrarian products by business entities of Lviv region}

\author{
M.G. Shulskyy \\ pretty_62@ukr.net
}

Stepan Gzhytskyi National University of Veterinary Medicine and Biotechnologies Lviv, Pekarska Str., 50, Lviv, 79010, Ukraine

\begin{abstract}
As a result of researches on the chosen theme, certain tendencies of production of agrarian products were identified as all categories of farms, and in the context of their separate groups. For a deeper insight into the nature of the research processes, a long period of development of agricultural production was chosen, namely the period of the former socialist economic system (1990) and the period of formation of market relations and their development to date (2000, 2010, $2015 \mathrm{p}$. and 2016). The selection of such a time frame for research allowed us to follow the state of production of agrarian products over a long period (1990-2016) and to identify certain trends based on the results of studies. The calculation of indices of agricultural products by categories of farms confirmed the presence of the revealed patterns.

Concerning the concretization of research on trends in the production of agricultural products by the subjects of the economy of Lviv region, the share of the main categories of farms in the production of agricultural products by the categories of farms was determined. The obtained results give a good reason to assert that the share of agrarian production by households grew from 1990
\end{abstract}

Shulskyy, M.G. (2017). Trends in the production of agrarian products by business entities of Lviv region. Scientific Messenger LNUVMB, 19(81), 7983. 
to 2000 (from 51.7\% to 90.2\%), and since 2000, this indicator gradually and dynamically decreases from 90,2 in 2000 to $64.1 \%$ in 2016. Agricultural enterprises are characterized by reverse trends - their share is dynamically increasing. We believe that these are natural processes and they will continue to evolve. Till what time? Answers to this question can only be given when conducting new research on a new topic.

Key words: trends, production, agrarian products, business entities, agricultural enterprises, households, agriculture.

\section{Вступ}

Суть постановки проблеми в даній публікації полягає в тому, щоб з'ясувати, в яких обсягах, в які періоди виробляли аграрну продукцію як всі категорії господарств у досліджуваній області, так і їх окремі групи. Це необхідно не тільки для того, щоб відобразити процеси виробництва продукції в умовах сьогодення, а й передбачити, які форми господарювання будуть розвиватися інтенсивніше, які повільніше і які 3 негативними результатами. Розв'язання цих проблем є фундаментом для подальших досліджень тенденцій розвитку виробництва аграрної продукції як у цілому в досліджуваній області, так і в розрізі окремих категорій сільськогосподарських виробників.

Аналіз останніх досліджень $і$ публікацій. Дослідження тенденцій виробництва аграрної продукції як на регіональному, так і державному рівнях проводила ціла плеяда науковців протягом тривалого періоду. Можна із впевненістю сказати, що ні одне аграрне видання на своїх шпальтах не уникає цієї теми - вона $\epsilon$ важливою складовою як минулих, так і сучасних досліджень і публікацій. Серед авторів, які досліджували і публікували результати досліджень, варто виділити таких, як В.Г. Андрійчук, Я.М. Гадзало, В.М. Жук, М.В. Зубець, Ю.О. Лупенко, М.Й. Малік, В.Я. Месель-Веселяк, Б.Й. Пасхавер, М.І. Пугачов, П.Т. Саблук, В.В. Юрчишин та інші (Mochernyi, 2000; Prysiazhniuk et al., 2011; Zbarskyi, 2011; MeselVeseliak, 2012; Paskhaver, 2013; Hadzalo et al., 2016).

Однак, які б не були глибокі, всебічні та комплексні дослідження, вони все-таки не вичерпують у повній мірі проблематику даної тематики. I насамперед це обумовлено тим, що кожен рік господарювання в аграрному секторі економіки вносить свої характерні особливості, доповнення і поправки у попередні твердження вчених. Все це в комплексі вимагає продовження всебічних досліджень за даною темою постійно, що ми фактично проводимо у цій публікації.

Постановка завдання. Завдання даної публікації полягає в тому, щоб дослідити, які зміни відбулись у виробництві аграрної продукції як всіма категоріями господарств, так і в розрізі їх основних груп в умовах Львівщини протягом 1990-2016 рр. Одержанні результати передбачено використати для прогнозування виробництва продукції основними сільськогосподарськими виробниками на подальші роки.

\section{Результати та їх обговорення}

Проведення дослідження виробництва продукції сільського господарства аграрними виробниками як Львівщини, так і інших областей України вимагає використання специфічних підходів до їх вивчення. Аналіз виробленої продукції в загальних вираженнях iii продукування всіма аграрними виробниками дає змогу представити виробництво всієї сільськогосподарської продукції в досліджуваній області. Приступаючи до реалізації поставленої мети, уточнімо найбільш важливі терміни і визначення які зустрічаються у даній публікації.

Для реалізації поставленого завдання використаємо матеріали Статистичного збірника (Korysko, 2017). Отож:

- продукція сільського господарства (у постійних цінах) - вартість продукції рослинництва і тваринництва, отриманої внаслідок вирощування сільськогосподарських культур і використання сільськогосподарських тварин, а також обсяги зміни незавершеного виробництва у рослинництві, обсяг вирощування молодих насаджень за рік та обсяг вирощування сільськогосподарських тварин (приплід, приріст живої маси);

- постійні ціни - середньозважені ціни року, прийнятого за основу для порівняння;

- господарства населення - домогосподарства, що здійснюють сільськогосподарську діяльність як 3 метою самозабезпечення продуктами харчування, так і з метою виробництва товарної сільськогосподарської продукції. До цієї категорії виробників віднесені також фізичні особи - підприємці, які проводять свою діяльність у галузі сільського господарства;

- $\quad$ сільськогосподарське підприємство - суб'єкт господарювання, який має право юридичної основи, або відокремлений підрозділ юридичної особи, що здійснює систематичну виробничу діяльність у галузі сільського господарства. До складу сільськогосподарських підприємств включають також фермерські господарства.

Наведені трактування, що містяться у Статистичному збірнику, в основному об'єктивно відображають суть і зміст кожного терміну. Саме через ці обставини ми використаємо дані визначення при підготовці даної статті. Це по-перше. А по-друге, цілком об'єктивно постало питання, а за який період слід використати статистичні матеріали? Це питання $\epsilon$ досить складним в самій його постановці та практичному вирішенні. Не будемо проводити дискусії з цієї надто важливої проблеми - це є тема для окремої публікації, а лише відзначимо, що нами обрані роки, коли відходила колишня соціалістична система аграрного господарювання (1990р.) і коли запрацювала відома передовим країнам світу і була маловідома у нашій державі ринкова економіка. Цей період представлений такими роками: 2000; 2010; 2015 і 2016. Наведену статистичну інформацію було порівняно між цими системами господарювання (2016 р. у \% до 1990 р.) і в самій ринковій системі (2016 р. у \% до 2015 р.). Одержані результати таких підходів наведені в таблиці 1. 
Продукція сільського господарства за категоріями господарств Львівщини (у постійних цінах 2010 року, млн грн)

\begin{tabular}{|c|c|c|c|c|c|c|c|}
\hline 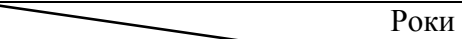 & 1990 & 2000 & 2010 & 2015 & 2016 & 201 & до \\
\hline Продукція & & & & & & 1990 & 2015 \\
\hline По всіх категоріях господарств & 10352,1 & 6971,6 & 7370,8 & 9024,9 & 9255,4 & 89,4 & 102,6 \\
\hline $\begin{array}{l}\text { 3 них } \\
\text { с.-г.** підприємства }\end{array}$ & 5001,4 & 679,8 & 1862,2 & 3045,0 & 3320,5 & 66,4 & 109,0 \\
\hline господарства населення & 5350,7 & 6291,8 & 5508,6 & 5979,9 & 5934,9 & 110,9 & 99,2 \\
\hline у тому числі рослинництва & 4818,8 & 3504,4 & 3802,2 & 5471,5 & 5768,3 & 119,7 & 105,4 \\
\hline $\begin{array}{l}3 \text { них } \\
\text { с.-г. підприємства }\end{array}$ & 2933,3 & 522,7 & 1034,1 & 2065,9 & 2302,5 & 78,4 & 111,5 \\
\hline господарства населення & 1885,5 & 2981,7 & 2768,1 & 3405,6 & 3465,8 & 183,6 & 101,8 \\
\hline тваринництва & 5533,3 & 3467,2 & 3568,6 & 3553,4 & 3487,1 & 63,6 & 98,1 \\
\hline $\begin{array}{l}3 \text { них } \\
\text { с.-г. підприємства }\end{array}$ & 2068,1 & 157,1 & 828,1 & 979,1 & 1018,0 & 49,2 & 104,0 \\
\hline господарства населення & 3465,2 & 3310,1 & 2740,5 & 2574,3 & 2469,1 & 71,3 & 95,5 \\
\hline
\end{tabular}

Примітки: * тут і надалі використано матеріали Статистичного збірника (Korysko, 2017);

$$
\text { ** с.-г. - скорочена назва «сільськогосподарські» }
$$

Дещо проаналізуємо із наведеної цифрової інформації. У 1990 р. було вироблено сільськогосподарської, продукції всіма категоріями господарств Львівщини на суму 10352,1 млн грн, із них сільськогосподарські підприємства продукували 5001,4 і господарства населення - 5350,7 млн грн - у 2000 р. відповідно: 6976,$6 ; 679,8$ і 6291,8; у 2016 р. ці показники складали: 9255,$4 ; 3320,5$ і 5934,9. Отож, у 1990 р. було вироблено найбільше продукції, а в 2000 р. найменше. У 2016 р. ці величини становлять проміжне значення.
При цьому варто зауважити, що господарства населення виробляли в минулому і виробляють в умовах сьогодення більше половини вартості продукованої аграрної продукції. Про умови досягнення таких показників господарствами населення розглянемо дещо пізніше, а зараз наведемо індекси зростання сільськогосподарської продукції як у цілому, так і за категоріями господарств Львівщини. В таблиці 2 подані ці показники, які діалектично взаємозв'язані з показниками таблиці 1.

Табличя 2

Індекси сільськогосподарської продукції за категоріями господарств Львівщини, \% до попереднього року

\begin{tabular}{|c|c|c|c|c|c|c|c|}
\hline \multirow{2}{*}{ Продукція } & \multirow[t]{2}{*}{1990} & \multirow[t]{2}{*}{2000} & \multirow[t]{2}{*}{2010} & \multirow[t]{2}{*}{2015} & \multirow[t]{2}{*}{2016} & \multicolumn{2}{|c|}{2016 «+», «-» до } \\
\hline & & & & & & 1990 & 2015 \\
\hline По всіх категоріях господарств & 90,9 & 108,3 & 95,7 & 97,1 & 102,6 & $+11,7$ & $+5,5$ \\
\hline $\begin{array}{l}3 \text { них } \\
\text { с.-г. підприємства }\end{array}$ & 81,7 & 81,4 & 103,4 & 95,0 & 109,0 & $+27,3$ & $+14,0$ \\
\hline господарства населення & 99,6 & 112,4 & 93,4 & 98,1 & 99,2 & $-0,4$ & $+1,1$ \\
\hline у тому числі рослинництва & 80,8 & 118,6 & 91,5 & 96,3 & 105,4 & $+24,6$ & $+9,1$ \\
\hline $\begin{array}{l}3 \text { них } \\
\text { с.-г. підприємства }\end{array}$ & 78,3 & 83,9 & 97,5 & 93,7 & 111,5 & $+33,2$ & $\begin{array}{r}+17,8 \\
\end{array}$ \\
\hline господарства населення & 84,6 & 127,9 & 89,5 & 97,9 & 101,8 & $+17,2$ & $+3,9$ \\
\hline тваринництва & 99,8 & 99,6 & 100,6 & 98,3 & 98,1 & $-1,7$ & $-0,2$ \\
\hline $\begin{array}{l}3 \text { них } \\
\text { с.-г. підприємства }\end{array}$ & 86,5 & 74,0 & 111,8 & 97,9 & 104,0 & $+17,5$ & $+6,1$ \\
\hline господарства населення & 107,7 & 101,3 & 97,7 & 98,4 & 95,9 & $-11,8$ & $-2,5$ \\
\hline
\end{tabular}

За твердженням С.В. Мочерного: «Індекси (лат. Index - показник, список) - відносні величини, які відображають співвідношення величин будь-якого економічного явища. У практиці статистичного та економічного аналізу застосовують два види індексів: індивідуальні та загальні» (Mochernyi, 2000). У наших дослідженнях ми використаємо індивідуальні індекси, які відображають зростання чи зниження обсягів виробництва сільськогосподарської продукції за досліджуваний рік у відсотковому порівнянні з відповідними показниками попереднього року як за всіма категоріями господарств, так і в розрізі їх окремих груп Львівщини. Загальною характеристикою визначених індексів $\epsilon$ строкатість їх величин протягом досліджуваних років. Ці тенденції проявляються як у всіх категоріях господарств, так і в розрізі: сільсько- господарських підприємств та господарств населення. Отож, коли індекси у всіх суб'єктах господарювання Львівщини відображають загальні тенденції змін у виробництві сільськогосподарської продукції, то в розрізі окремих груп господарств прослідковуються існуючі закономірності щодо їх відсоткових співвідношень як у господарствах населення, так і в сільськогосподарських підприємствах.

3 огляду на сказане неабиякий інтерес становлять індекси за 2016 р., які характеризуються збільшення порівнюваних величин до 2015 р. як всіма категоріями господарств, так і в галузевому розрізі, за винятком продукції тваринництва (обсяг виробництва тваринницької продукції зменшився на 1,9\% у 2016 р. проти рівня 2015 р.). Коли аналізувати визначенні індекси 2016 р. в розрізі окремих груп аграрних виро- 
бників, то можна виявити певні тенденції. Так, зокрема, у сільськогосподарських підприємствах індекси характеризують зростання виробництва продукції сільського господарства як у загальних обсягах, так і в галузевому розрізі. Зовсім інші тенденції спостерігаються при виробництві продукції господарствами населення, майже всі індекси характеризуються зниженими величинами, за винятком деякого зростання продукування рослинницької продукції - всього на $1,8 \%$.

Аналізуючі індекси дають підстави стверджувати, що сільськогосподарські підприємства мають вищі темпи зростання виробництва продукції сільського господарства, ніж господарства населення. А це, сво- єю чергою, показує, що серед аграрних виробників найбільш перспективними формами господарювання стають крупні форми господарських структур, які уособлюються в сільськогосподарських підприємствах.

Вище у цій публікації було зазначено, що дещо пізніше буде дано відповідь на питання: чому господарства населення виробляють значні обсяги сільськогосподарської продукції (табл. 1)? Для формування відповідей на поставлене питання нами підготовлена інформація про частку основних категорій господарств Львівщини у виробництві сільськогосподарської продукції, яка подана в таблиці 3.

Табличя 3

Частка основних категорій господарств Львівщини у виробництві продукції сільського господарства, \%

\begin{tabular}{|c|c|c|c|c|c|c|c|}
\hline \multirow{2}{*}{ Продукція } & \multirow[t]{2}{*}{1990} & \multirow[t]{2}{*}{2000} & \multirow[t]{2}{*}{2010} & \multirow[t]{2}{*}{2015} & \multirow[t]{2}{*}{2016} & \multicolumn{2}{|c|}{2016 «+»»,«-» до } \\
\hline & & & & & & 1990 & 2015 \\
\hline $\begin{array}{l}\text { Продукція сільського господарс- } \\
\text { тва }\end{array}$ & $\frac{48,3^{*}}{51,7^{* *}}$ & $\frac{9,8}{90,2}$ & $\frac{25,3}{74,7}$ & $\frac{33,7}{66,3}$ & $\frac{35,9}{64,1}$ & $\frac{-12,4}{+12,4}$ & $\frac{+2,2}{-2,2}$ \\
\hline $\begin{array}{l}\text { у тому числі } \\
\text { рослинництва }\end{array}$ & $\frac{60,9}{39,1}$ & $\frac{14,9}{85,2}$ & $\frac{27,2}{72,8}$ & $\frac{37,8}{62,2}$ & $\frac{39,9}{60,1}$ & $\frac{-21,0}{+21,0}$ & $\frac{+2,1}{-2,1}$ \\
\hline тваринництва & $\frac{37,4}{62,6}$ & $\frac{4,5}{95,5}$ & $\frac{23,2}{76,8}$ & $\frac{27,6}{72,4}$ & $\frac{29,2}{70,8}$ & $\frac{-8,2}{+8,2}$ & $\frac{+1,6}{-1,6}$ \\
\hline
\end{tabular}

Примітки: * чисельник - с.-г. підприємств;

** знаменник - господарства населення.

Отож, за колишньої системи (1990р.) частка господарств населення Львівщини у виробництві продукції сільського господарства становила 51,7\%, у тому числі рослинництва складала 39,1 і тваринництва 62,6\%. У 2000 р. ці цифри значно зросли та починаючи 32010 р. відбуваються динамічні процеси скорочення їх частки і в 2016 р. вони зменшилися відповідно до, \%: 64,1; 60,1 і 70,8. 3 іншого боку, питома вага виробництва аграрної продукції сільськогосподарськими підприємствами має тенденції до зростання. Чи буде це проводитися і надалі та до якого періоду? Безумовно, процеси розвиватися будуть у цьому напрямку, однак до якого періоду - це уже тема для окремих подальших наукових досліджень. Щодо причин значної частки господарств населення Львівщини у виробництві аграрної продукції, то вони обгрунтовані у попередній статті автора (Shulskyi, 2016).

\section{Висновки}

На основі проведеного дослідження можна констатувати, що виробництво аграрної продукції суб'єктами господарювання Львівщини, хоча і має тенденцію до зростання, однак все-таки не досягнуто дореформеного рівня (1990р.). Щодо окремих груп господарств, то спостерігаються динамічні процеси збільшення виробництва продукції сільськогосподарськими підприємствами і одночасно строкатість такого розвитку щодо господарств населення (табл. 1). Визначені індекси сільськогосподарської продукції за категоріями господарств Львівщини підтверджують сказане (табл. 2). Дані таблиці 3 виявляють чіткі тенденції щодо збільшення частки виробництва аграрної продукції сільськогосподарськими підприємствами і зменшення $\dddot{11}$ - господарствами населення. Ми вважа- ємо, що це є закономірні тенденції і вони будуть продовжуватися й надалі. Проте дати відповіді, до якого саме періоду ці тенденції будуть розвиватися у даній публікації не є можливим. Це обумовлено двома причинами. По-перше, обмеженість даної статті в сторінковому обчисленні, а по-друге, слід змінювати напрями дослідження. А це уже тема, щоБ вимагає проведення нових наукових досліджень і відповідно нових публікацій.

\section{Бібліографічні посилання}

Prysiazhniuk, M.V., Zubets, M.V., Sabluk, P.T., MeselVeseliak, V.Ia., Fedorov, M.M., Hryshchenko, O.Iu. (2011). Ahrarnyi sektor Ukrainy (stan i perspektyvy rozvytku). K.: NNTs IAE (in Ukrainian).

Hospodarskyi Kodeks Ukrainy (2014). Chynne zakonodavstvo Ukrainy zi zminamy ta dopovnenniamy stanom na 3 veresnia 2014 r.: (vidpovidaie ofitsiinomu tekstovi). K.: «Tsentr uchbovoi literatury» (in Ukrainian).

Mochernyi, S.V. (2000). Ekonomichna entsyklopediia: U trokh tomakh. T. 1. K.: Vydavnychyi tsentr «Akademiia» (in Ukrainian).

Zbarskyi, V.K. (2011). Rozvytok dribnotovarnoho sektoru silskykh poselen Ukrainy: Monohrafiia. K.: NNTs IAE (in Ukrainian).

Mesel-Veseliak, V.Ia. (2012). Formy hospodariuvannia v silskomu hospodarstvi Ukrainy (rezultaty, problemy, vyrishennia). Ekonomika APK. 1, 13-23 (in Ukrainian).

Paskhaver, B.I. (2013). Kontsentratsiia ta efektyvnist silskoho hospodarstva. Ekonomika APK. 1, 16-23 (in Ukrainian). 
Hadzalo, Ya.M., Lupenko, Yu.O., Puhachov, M.I. (2016). Rozvytok ekonomiky silskoho hospodarstva Ukrainy v 2011 - 2015 rr.: Nauk.dop. Natsionalnyi naukovyi tsentr «Instytut ahrarnoi ekonomiky». K.: NNTs «IAE», 546 (in Ukrainian).

Korysko, H. (2017). Silske hospodarstvo Lvivskoi oblasti. Statystychnyi zbirnyk. Lviv (in Ukrainian).

Zymovina, S.I. (2016). Statystychnyi shchorichnyk Lvivskoi oblasti za 2015 rik. Chastyna 1. Lviv (in Ukrainian).

Hadzalo, Ya.M., Bashchenko, M.I., Zhuk, V.M., Lupenko, Yu.O. (2016). Stratehiia rozvytku silskohospodarskoho vyrobnytstva $v$ Ukraini na period do 2025 roku. K.: Ahrarna nauka (in Ukrainian).

Shulskyi, M.H. (2016). Hospodarstva naselennia: tendentsii zmin ploshch zemelnykh uhid i vyrobnytstva ahrarnoi produktsii. Naukovyi visnyk Lvivskoho natsionalnoho universytetu veterynarnoi medytsyny ta biotekhnolohii imeni S.Z. Hzhytskoho. Seriia «Ekonomichni nauky». 18, 2(69), 183-188 (in Ukrainian).

Received 14.09.2017

Received in revised form 5.10.2017

Accepted 10.10.2017 